\title{
EFFECT OF POTASSIUM FERTILIZATION LEVELS ON GROWTH, YIELD AND QUALITY OF SUNFLOWER CULTIVARS \\ (Helianthus annuus L.)
}

\author{
Saad A. M. Al-Doori \\ General Science Dept. \\ College of Basic Education
}

\author{
A. M. S. AL-Delymi \\ Chemistry Dept. \\ College of Education
}

Univ. of Mosul, Iraq

\begin{abstract}
The study included two field experiments for sunflower crop conducted during spring growing season of 2008 in two locations. The first was in AL-Rashidia (20 $\mathrm{km})$ west north Mosul city, the second ones was in AL-Hamdanea $(30 \mathrm{Km})$ east of Mosul city. The main objective was to find out the effect of potassium fertilization levels on growth, yield and quality of three sunflower cultivars. Each experiment was conducted according to factorial experiment in a randomized completely block design with three replications. It included three levels of potassium $(0,30$ and $60 \mathrm{~kg}$ $\mathrm{k}$ per hectare ${ }^{-1}$ ) were applied to the soil during the sowing period, with three cultivars of sunflower crop (Saturn, Gordis and Majak).

The results could be summarized as follows:

The cultivar Gordis gave a high level for most growth, yield and quality parameters in both locations. Application of $30 \mathrm{~kg} \mathrm{~K}$ per hectare ${ }^{-1}$ led to a significant increase in plant height, leaf area, disc diameter, number of seeds per head, weight of thousand seed, seed yield, oil percentage and oil yield, while increasing concentration of potassium up to $60 \mathrm{~kg} \mathrm{~K}$ per hectare ${ }^{-1}$ caused a significant increase in protein percentage in AL-Rashidia and AL-Hamdanea locations. The interaction between the cultivars and potassium fertilization levels was significant in some growth, yield and quality parameters, the Gordis cultivar with potassium application to the soil with concentration $30 \mathrm{~kg} \mathrm{k} \cdot \mathrm{ha}^{-1}$ was superior and gave highest values for plant height, stem diameter, leaf area, number of seeds.head ${ }^{-1}$, weight of thousand seed, oil percentage, oil yield, protein percentage and protein yield in AL-Rashidia location only, while the interaction between cultivars and potassium fertilization levels was significant in number of seeds per head and weight of thousand seed in AL- Hamdanea location only.

Key words: Potassium Fertilization, Sunflower Cultivars, Helianthus annuus. Corresponding author:
\end{abstract}

Received 17/4/2012 Accepted 15/10/2012

\section{INTRODUCTION}

Sunflower (Helianthus annuиs L.) is an important edible oil crops, ranking next to soybean (Khan, 1999). It is a drought tolerant and short duration crop and has a wider range of adaptability. Therefore, more care should be given to this crops to improve the productivity to meet the shortage of vegetable oil (Ibrahim et al., 2003). Its seed contain high oil content ranging from 40-50 percent and it is rich in protein 23 percent (Mohamed et al., 1992 and Sangoi and Kruse, 1993). Moreover, its oil quality is better due to higher percentage of linoleic acid and low percentage of linolenic acid which is the most desirable character, lacking in other 
oils (Annaduri et al., 1994). Nitrogen, phosphorous and potassium are major elements essential for plant growth and development. To date the use of chemical fertilizers has been confined mainly to the application of nitrogen, phosphorous and potassium. There role are well documented in photosynthesis, increasing enzyme activity, improving synthesis of protein, carbohydrates and fats, translocation of photosynthetic, enabling their ability to resist pests and diseases. Potassium also plays key role in increasing crop yield and improving the quality of product (Tisdale et al., 1985 and Soleimanzadeh et al., 2010).

In addition to the other factors that are responsible for increasing yield per hectare, is the application of potassium which plays a remarkable role in boosting up production (Blamey et al., 1979). The effect of potassium application on sunflower plant growth, yield and quality was reported by some investigators, who found that increasing potassium level led to a significant increase in plant height (Sirbu and Ailincai, 1992), no. of leaves, leave area and head diameter (Lewis et al., 1991). Response of sunflower to potassium application was studied by many investigators: Carter, (1978); Shinde et al., (1993); Khan, (1999) and Ahmad et al., (2001) who reported that the application of $150 \mathrm{~kg}$ potassium. ha ${ }^{-1}$ increased sunflower no. of seeds.head ${ }^{-1}$, weight of thousand seed, fertility, and total yield.

So, the objective of this trial was to study the effect of three potassium fertilization levels on growth, yield and certain quality traits of three sunflower cultivars.

\section{METERALS AND METHODS}

Tow filed experiments were carried out during 2008 season at the experimental farm, the first was in AL-Rashidia $20 \mathrm{~km}$ west north Mosul city, the second was in AL-Hamdanea $30 \mathrm{Km}$ east of Mosul city at Nineveh province, to investigate the effect of three levels of potassium fertilization $(0,30$ and $60 \mathrm{~kg} \mathrm{k}$ hectare $\left.^{-1}\right)$ on the growth, yield and certain quality traits of three sunflower cultivars (Saturn, Gordis and Majak). Each experiment included nine treatments comprising the combinations of three cultivars and three potassium levels with three replications.

Seeds of these cultivars were obtained from the crops industrial company, Baghdad. The experimental design was factorial experiment in a Randomized Completely Block Design with three replications according to Steel and Torrie, (1980). Then Duncan's multiple range test (Duncan, 1955) was used to compare among means (SAS, 2001). A representative soil sample $(0-30$ and $30-60 \mathrm{~cm})$ was taken before planting, (table1) to study some physical, chemical and nutritional properties using the methods described by Black, (1965); Jackson, (1973); Page et al., (1982) and Tandon, (1999).

Seeds were sown in April $2^{\text {nd }}$ and $6^{\text {th }}$ and harvested in August $4^{\text {th }}$ and $8^{\text {th }}$ for 2008 season for the two locations respectively, in hills $30 \mathrm{~cm}$ apart on ridges $40 \mathrm{~cm}$ apart to attain a plant density of 83.333 plants.ha $^{-1}$. Super phosphate $120 \mathrm{~kg}$ per hectare $^{-1}\left(45 \% \quad \mathrm{P}_{2} \mathrm{O}_{5}\right)$ and potassium levels $\left(48 \% \mathrm{~K}_{2} \mathrm{O}\right)$ were applied to the soil during the sowing period, Nitrogen fertilizers was applied in the form of urea 80 $\mathrm{kg} \cdot$ hectare $^{-1}(46 \% \mathrm{~N})$ in two equal doses, prior to the first and second irrigation. Each plot $14.4 \mathrm{M}^{2}\left(6^{*} 2.4\right)$ included six rows and six meters long. The plant were 
thinned to one plant per hill 14 days after sowing. The external two rows were left as border. Two of the remaining rows were devoted for estimating plant growth and some characteristics. The first irrigation was applied after 5 days from sowing and then irrigation was scheduled at about four days intervals. Normal cultural practices of growing sunflower were conducted in the usual manner followed by the farmers of the district. At heading, the heads of the two inner rows were bagged early to seed development to avoid birds damage until maturity. The following data were recorded: plant height $(\mathrm{cm})$, stem diameter $(\mathrm{cm})$, leaf area, and head diameter $(\mathrm{cm})$. At harvest, ten plants were taken randomly from the two inner rows of each experimental plot and left for two weeks until fully air dried, then the following data were calculated; number of seeds per head, weight of thousand seed, hulls percentage, fertility percentage, yield and oil yield (ton.hectare ${ }^{-1}$ ). Oil seed content was determined using Soxhlet method (Anonymous, 1980) and seed nitrogen concentration was measured by microkjeldahl method, then protein percentage was calculated via multiplying the nitrogen percentage by the converting factor 6.25 (Agrawal et al., 1980).

Table (1): Physical and chemical characters of soil experiments at both locations.

\begin{tabular}{|c|c|c|c|c|}
\hline \multicolumn{5}{|c|}{ physical characters } \\
\hline Locations & \multicolumn{2}{|c|}{ AL-Rashidia } & \multicolumn{2}{|c|}{ AL-Hamdanea } \\
\hline Depth (cm.) & $0-30$ & $30-60$ & $0-30$ & $30-60$ \\
\hline Sand $(\%)$ & 57.00 & 50.00 & 47.00 & 39.00 \\
\hline Silt (\%) & 25.00 & 30.00 & 33.00 & 33.00 \\
\hline Clay $(\%)$ & 18.00 & 20.00 & 20.00 & 28.00 \\
\hline Texture & Sandy loom & Sandy loom & Silty sand & Silty sand loom \\
\hline \multicolumn{5}{|c|}{ chemical characters } \\
\hline O.M. (g.kg $\left.{ }^{-1}\right)$ & 1.24 & 0.82 & 1.46 & 0.98 \\
\hline Available N (ppm) & 44.20 & 34.90 & 40.50 & 20.90 \\
\hline Available P (ppm) & 12.85 & 9.12 & 11.72 & 10.54 \\
\hline Available K (ppm) & 144.00 & 138.00 & 134.00 & 122.00 \\
\hline Total $\mathrm{CaCo}_{3}\left(\mathrm{~g} \cdot \mathrm{kg}^{-1}\right)$ & 23.50 & 21.80 & 16.20 & 12.10 \\
\hline $\mathrm{pH}$ & 7.20 & 7.33 & 7.62 & 7.68 \\
\hline E.C. $\left(\mathrm{mmhos} \mathrm{cm}^{-1}\right)$ & 0.92 & 0.41 & 0.76 & 0.48 \\
\hline
\end{tabular}

\section{RESULTS AND DISCUSSION}

1- Effect of cultivars: Data in table (2) revealed that Gordis cultivar had taller $(114.10,115.87 \mathrm{~cm})$ and thicker $(2.11,2.56 \mathrm{~cm})$ plant then those of Saturn and Majak in both locations AL-Rashidia and AL-Hamdanea respectively. The result of leaf area showed that Gordis cultivar significantly exhibited higher leaf area (3160, $3298 \mathrm{~cm}^{2}$.plant) than those of Majak and Saturn cultivars in the two locations respectively. The differences among the three cultivars in the leaf area may be attributed to the general varietals differences in the plant height and number of internodes per plant (Mohamed et al., 1992; Sangoi and Kruse, 1993 and Abd ELSamie et al., 1995). In this concern, Salama (1996) showed that taller cultivars had more leaves and leaf primordial than the others sunflower cultivars. It can be also noted that the head diameter of Gordis cultivar was greeter than Saturn and Majak cultivars at both locations. Mean values of seed yield, yield components and some related traits for the three tested cultivars are presented in table (2). The data 
revealed that Gordis cultivar surpassed Saturn and Majak cultivars in the head characteristic (head diameter, no. of seeds.head ${ }^{-1}$, weight of thousand seed), Moreover, Saturn surpassed Majak in those traits in both locations. This means that Gordis plants were more efficient to accumulate dry mater in their head. Regarding to the seed characters studied i.e. weight of thousand seed, hulls, fertility and oil percentage, data showed that there were a significant variations among the three tested sunflower cultivars in both locations. Gordis cultivar surpassed significantly Saturn and Majak cultivars in no. of seeds.head ${ }^{-1}(1152.66,1181.00)$, weight of thousand seed, yield and oil yield $\left(2.89,2.82,1.25,1.23\right.$ ton.hectare $\left.^{-1}\right)$ in both locations, respectively. However, fertility seeds percentage showed fluctuated direction in the two locations, where Gordis cultivar was the highest in both locations. On the other hand, Majak cultivar was the medium in both locations. The superiority of Gordis cultivar in the most seed characters may be due to that Gordis cultivar had better vegetative growth and hence photosynthetic area which led to more carbohydrates which was translocated from the source (leaves and stem) to the sink (seeds) (Carter, 1978 and Mengel and Kirkby, 1982). The results showed that the number of seeds per head, weight of thousand seed and yield, oil yield (ton.hectare ${ }^{-1}$ ) were always significantly higher for Gordis than that for Saturn and Majak varieties.

2- Effect of potassium fertilization: Data presented in table (3) showed that increasing potassium level from 0 to $30\left(\mathrm{Kg} \mathrm{k} \mathrm{ha}^{-1}\right)$ significantly increased stem diameter, leaf area and head diameter at the both locations, While these traits appeared to have negative response to $60 \mathrm{~kg} \mathrm{k} \mathrm{ha}^{-1}$. This could be attributed to the highly available potassium in the experimental site in both locations (table 1) also showed that the available potassium in the soil is in the average of medium level which is ranged from 128-141ppm, and these results are in agreement with the classification of Bergmann, (1965), although sunflower required a high quantity of potassium, this reflected the response of the crop to this element when increasing the concentration from 0 to $30 \mathrm{~kg} \mathrm{k} \mathrm{ha}^{-1}$. The beneficial effect of potassium on plant height may be due to its role in enhancing photosynthesis. In this concern, increasing potassium fertilizer levels increased plant height as was found by Sirbu and Ailincai, (1992) and Shinde et al., (1993). The leaf area was increased significantly by adding potassium fertilizer up to $30 \mathrm{~kg} \mathrm{k} \cdot \mathrm{ha}^{-1}$ as compared to the check and the high level of potassium in both locations. However, increasing potassium level up to $60 \mathrm{~kg} \mathrm{k} \mathrm{ha}^{-1}$ had low significant effect on these traits. These results means that potassium application up to $30 \mathrm{~kg} \mathrm{k} \mathrm{ha}^{-1}$ was enough to increase the leaf area. These findings confirmed the results obtained by Shinde et al., (1993); Annaduri et al., (1994) and Khan, (1999) who found that the application of $150 \mathrm{~kg} \mathrm{k}$ $\mathrm{ha}^{-1}$ increased sunflower area.plant ${ }^{-1}$ and number of leaves per plant. The stimulatory effect of potassium in sunflower plant may be due to its role in enhancing metabolic process. These results are in harmony with those obtained by Pervaiz et al., (1999); Ahmad et al., (2001); Karim and Hassain, (2002) and Mohammad et al., (2008). Data reported in table (3) demonstrated that the number of seeds per head significantly increased by increasing potassium application levels from 0 to $30 \mathrm{~kg} \mathrm{k} \mathrm{ha}^{-1}$ in both locations. Many researchers concluded that increasing potassium application rates increased number of seeds per head (Shinde et al., 1993 
and Ahmad et al., 2001). The obtained data showed that weight of thousand seed, hulls, fertility, total yield and oil yield were increased significantly as the potassium application levels was increased from 0 to $30 \mathrm{~kg} \mathrm{k} \mathrm{hectare}^{-1}$ in the two locations. These results are in agreement with those reported by Roga et al., (1984); Lewis et al., (1991); Harmati, (1993); and Annaduri et al., (1994) who reported that potassium application increased seed yield to 40\%. Soleimanzadeh et al., (2010) found that the increases in yield through potassium application may be due to its key role in increasing crop yield and improving the quality of product and hence, the transport of nutrients is essential to metabolism in active areas. Similar results were obtained by Ahmad et al., (2001) who found that head diameter, weight of thousand seed and oil yield were increased with increasing potassium application rates from 0 to $150 \mathrm{~kg} \mathrm{k} \mathrm{ha}^{-1}$. On the contrary, the fertility percentage and seed oil percentage were decreased with increasing potassium application up to $60 \mathrm{~kg} \mathrm{k}$. ha ${ }^{-}$ ${ }^{1}$. The decrease in the fertility seed may attributed to more light translocation to the seeds by increasing potassium level. However, the decrease in seed oil contents by potassium fertilizer may be due to the increase in seed protein content (Chitdeshwari et al., 2002). In this concern, Many researchers reported that the potassium application to sunflower caused a reduction in seed oil percentage (Nazakat et al., 2003).

\section{3- Effect of interaction between cultivars and potassium fertilization:} Interaction between the studying factors (cultivars and potassium fertilization) showed significant effects on some growth characters, yield components and quality in both locations as illustrated in table (5). The interaction between the cultivars and potassium fertilization for the other investigated traits were not statistically significant in both locations, therefore the data were excluded.

Data illustrated in table (4) show generally that Saturn, Gordis and Majak cultivars appeared to be clearly affected by increasing rate of potassium fertilization levels up to $30 \mathrm{~kg} \mathrm{k} \mathrm{ha}^{-1}$ for the traits of plant height $(120 \mathrm{~cm})$, stem diameter $(2.4 \mathrm{~cm})$, leaf area, number of seeds.head ${ }^{-1}$, weight of thousand seed, oil percentage $(43.7 \%)$, oil yield, protein percentage and protein yield only in AL-Rashidia location, while the interaction between cultivars and potassium fertilization levels was significant in number of seeds.head ${ }^{-1}$ and weight of thousand seed only in ALHamdanea location, while they appeared to be little response to $60 \mathrm{~kg} \mathrm{k} \mathrm{ha}^{-1}$ for those traits. On the other hand, Gordis cultivar reflected the greatest response to potassium fertilization levels up to $30 \mathrm{Kg} \mathrm{k} \mathrm{ha}^{-1}$ for these traits, with this regard, Prunty, (1981); Faizani, et al., (1990); Sarmah, et al., (1994); Conley and Barta, (2003) and Khan, (1999) found that fertilization with $150 \mathrm{~kg} \mathrm{k} \mathrm{ha}{ }^{-1}$ produced maximum weight of thousand seed $(53.71 \mathrm{~g})$ and seed yield $\left(4153 \mathrm{~kg} \mathrm{ha}^{-1}\right)$. On the other hand, the response rate of Saturn and Majak cultivars to potassium fertilizer was low with increasing potassium fertilization levels more than $60 \mathrm{~kg} \mathrm{k} \mathrm{ha}^{-1}$ for the most of these traits. It could be concluded that the tallest cultivars i.e. Gordis responded positively to high potassium fertilization levels compared with the shorter cultivars Saturn and Majak. (Osman and Abolila, 1984; Ibrahim et al., 2003; Govt 2004; Brar, 2007 and Rathika et al., 2008). The insignificant effect between cultivars and potassium fertilization levels on other characteristic showed that each of these two factors acted independently on these traits. 
Mesopotamia J. of Agric. Vol. (42) No. (1) 2014
ISSN: 2224-9796 (Online) ISSN: 1815-316 X (Print)

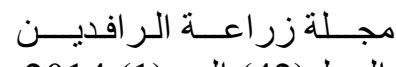

المجلد(42) العدد(1) 2014

Table (2): Means number of some growth characters, yield components and quality as affected by cultivars in both locations.

\begin{tabular}{|c|c|c|c|c|c|c|c|c|c|c|c|c|c|c|}
\hline locations & cultivars & $\begin{array}{l}\text { plant } \\
\text { height } \\
(\mathrm{cm})\end{array}$ & $\begin{array}{c}\text { stem } \\
\text { diameter } \\
(\mathrm{cm})\end{array}$ & $\begin{array}{l}\text { leaf area } \\
\left(\mathrm{cm}^{2} \text {.plant }\right)\end{array}$ & $\begin{array}{c}\text { head } \\
\text { diameter } \\
(\mathrm{cm})\end{array}$ & $\begin{array}{c}\text { no. of } \\
\text { seeds } \\
\text { per head }\end{array}$ & $\begin{array}{c}1000 \\
\text { seed } \\
\text { weight }\end{array}$ & $\begin{array}{l}\text { hulls } \\
(\%)\end{array}$ & $\begin{array}{l}\text { fertility } \\
(\%)\end{array}$ & $\begin{array}{c}\text { yield } \\
\left(\text { ton.ha }^{-1}\right)\end{array}$ & $\begin{array}{l}\text { oil } \\
(\%)\end{array}$ & $\begin{array}{l}\text { oil yield } \\
\left(\text { ton.ha }^{-1}\right)\end{array}$ & $\begin{array}{l}\text { protein } \\
(\%)\end{array}$ & $\begin{array}{c}\text { protein } \\
\text { yield } \\
\text { (ton.ha }^{-1} \text { ) }\end{array}$ \\
\hline \multirow{3}{*}{ AL-Rashidia } & Saturn & $106.22 b$ & $1.88 \mathrm{~b}$ & $2613.72 b$ & $19.47 \mathrm{~b}$ & $1062.53 \mathrm{~b}$ & $69.16 \mathrm{~b}$ & $51.78 \mathrm{~b}$ & $83.24 b$ & $2.18 \mathrm{~b}$ & $42.18 \mathrm{~b}$ & $0.923 b$ & $13.57 \mathrm{c}$ & $0.296 \mathrm{~b}$ \\
\hline & Gordis & $114.10 \mathrm{a}$ & $2.11 \mathrm{a}$ & $3160.68 \mathrm{a}$ & $21.25 \mathrm{a}$ & $1152.66 \mathrm{a}$ & $74.97 \mathrm{a}$ & $54.64 a$ & $86.07 \mathrm{a}$ & $2.89 \mathrm{a}$ & $43.15 a$ & $1.250 \mathrm{a}$ & $13.85 b$ & $0.402 \mathrm{a}$ \\
\hline & Majak & $103.41 \mathrm{c}$ & $1.76 \mathrm{c}$ & $2526.55 c$ & $18.76 \mathrm{c}$ & $1030.36 c$ & $65.28 \mathrm{c}$ & $50.32 c$ & $82.13 c$ & $2.08 \mathrm{c}$ & $41.54 \mathrm{c}$ & $0.865 \mathrm{c}$ & $14.14 \mathrm{a}$ & $0.294 b$ \\
\hline \multirow{3}{*}{ AL-Hamdanea } & Saturn & $108.00 \mathrm{~b}$ & $2.13 b$ & $2724.17 \mathrm{~b}$ & $19.29 b$ & $1064.09 \mathrm{~b}$ & $71.00 \mathrm{~b}$ & $52.23 b$ & $83.03 \mathrm{~b}$ & $2.21 \mathrm{~b}$ & $41.29 b$ & $0.915 b$ & $14.07 \mathrm{~b}$ & $0.312 \mathrm{~b}$ \\
\hline & Gordis & $115.87 \mathrm{a}$ & $2.56 \mathrm{a}$ & $3298.35 \mathrm{a}$ & $21.73 a$ & $1181.00 \mathrm{a}$ & $75.50 \mathrm{a}$ & $53.43 \mathrm{a}$ & $85.49 \mathrm{a}$ & $2.82 \mathrm{a}$ & $43.63 \mathrm{a}$ & $1.234 \mathrm{a}$ & $14.11 \mathrm{~b}$ & $0.399 \mathrm{a}$ \\
\hline & Majak & $104.97 \mathrm{c}$ & $1.96 \mathrm{c}$ & $2596.22 c$ & $18.59 \mathrm{c}$ & $1033.69 c$ & $65.99 c$ & $50.66 c$ & $81.75 c$ & $2.02 \mathrm{c}$ & $41.23 c$ & $0.836 \mathrm{c}$ & $14.63 \mathrm{a}$ & $0.295 b$ \\
\hline
\end{tabular}

* The mean values within column followed by the different letter are significant at 0.01 and 0.05 probability levels, respectively.

Table (3): Means number of some growth characters, yield components and quality as affected by potassium fertilization levels in both locations.

\begin{tabular}{|c|c|c|c|c|c|c|c|c|c|c|c|c|c|c|}
\hline locations & $\begin{array}{c}\mathrm{K} \\
\text { levels } \\
\left(\mathrm{kg} \cdot \mathrm{ka}^{-1}\right)\end{array}$ & $\begin{array}{l}\text { plant } \\
\text { height } \\
(\mathrm{cm})\end{array}$ & $\begin{array}{l}\text { stem } \\
\text { diameter } \\
(\mathrm{cm})\end{array}$ & $\begin{array}{l}\text { leaf area } \\
\left(\mathrm{cm}^{2} \text {.plant }\right)\end{array}$ & $\begin{array}{l}\text { head } \\
\text { diameter } \\
(\mathrm{cm})\end{array}$ & $\begin{array}{c}\text { no. of } \\
\text { seeds } \\
\text { Per head }\end{array}$ & $\begin{array}{c}1000 \\
\text { seed } \\
\text { weight }\end{array}$ & $\begin{array}{r}\text { hulls } \\
(\%)\end{array}$ & $\begin{array}{c}\text { fertility } \\
(\%)\end{array}$ & $\begin{array}{c}\text { yield } \\
\left(\text { ton.ha }^{-1}\right)\end{array}$ & $\begin{array}{l}\text { oil } \\
(\%)\end{array}$ & $\begin{array}{l}\text { oil yield } \\
\left(\text { ton.ha }^{-1}\right)\end{array}$ & $\begin{array}{l}\text { protein } \\
(\%)\end{array}$ & $\begin{array}{l}\text { protein } \\
\text { yield } \\
\left.\text { (ton.ha }{ }^{-1}\right)\end{array}$ \\
\hline \multirow{3}{*}{ AL-Rashidia } & 0 & $99.99 \mathrm{c}$ & $1.49 \mathrm{c}$ & $2582.61 \mathrm{c}$ & $18.98 \mathrm{c}$ & $1011.02 \mathrm{c}$ & $65.60 \mathrm{c}$ & $50.65 c$ & $82.18 \mathrm{~b}$ & $2.07 \mathrm{c}$ & $41.62 \mathrm{~b}$ & $0.863 \mathrm{c}$ & $13.42 \mathrm{c}$ & $0.277 \mathrm{~b}$ \\
\hline & 30 & $114.64 a$ & $2.28 \mathrm{a}$ & $2993.70 \mathrm{a}$ & $20.77 \mathrm{a}$ & $1166.05 a$ & $72.97 \mathrm{a}$ & $53.65 a$ & $84.91 \mathrm{a}$ & $2.59 a$ & $42.90 \mathrm{a}$ & $1.117 \mathrm{a}$ & $13.65 \mathrm{~b}$ & $0.354 a$ \\
\hline & 60 & $109.10 \mathrm{~b}$ & $1.98 \mathrm{~b}$ & $2724.64 b$ & $19.72 b$ & $1068.48 b$ & $70.84 b$ & $52.44 b$ & $84.35 \mathrm{a}$ & $2.49 \mathrm{~b}$ & $42.35 \mathrm{a}$ & $58 \mathrm{~b}$ & $14.48 \mathrm{a}$ & $0.361 \mathrm{a}$ \\
\hline \multirow{3}{*}{ AL-Hamdanea } & 0 & $100.88 \mathrm{c}$ & $1.79 \mathrm{c}$ & $2703.73 c$ & $19.21 \mathrm{~b}$ & $1025.69 \mathrm{c}$ & $67.07 \mathrm{c}$ & $51.38 \mathrm{~b}$ & $82.17 \mathrm{c}$ & $2.13 b$ & $41.33 b$ & $0.886 \mathrm{c}$ & $13.60 \mathrm{c}$ & $0.288 b$ \\
\hline & 30 & $117.20 \mathrm{a}$ & $2.66 \mathrm{a}$ & $3037.03 \mathrm{a}$ & $20.43 a$ & $1164.39 \mathrm{a}$ & $73.71 \mathrm{a}$ & $52.78 \mathrm{a}$ & $84.42 \mathrm{a}$ & $2.55 \mathrm{a}$ & $42.48 \mathrm{a}$ & $1.087 \mathrm{a}$ & $14.02 \mathrm{~b}$ & $0.356 \mathrm{a}$ \\
\hline & 60 & $110.77 \mathrm{~b}$ & $2.20 \mathrm{~b}$ & $2877.98 b$ & $19.98 \mathrm{a}$ & $1088.71 \mathrm{~b}$ & $71.71 \mathrm{~b}$ & $52.16 \mathrm{a}$ & $83.67 \mathrm{~b}$ & $2.38 \mathrm{a}$ & $42.33 a$ & $1.012 \mathrm{~b}$ & $15.19 a$ & $0.361 \mathrm{a}$ \\
\hline
\end{tabular}

* The mean values within column followed by the different letter are significant at 0.01 and 0.05 probability levels, respectively. 
Mesopotamia J. of Agric. Vol. (42) No. (1) 2014
ISSN: 2224-9796 (Online) ISSN: 1815-316 X (Print)

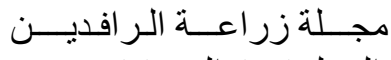

المجلد(42) العدد(1) 2014

Table (4): Means number of some growth characters, yield components and quality as affected by interaction between cultivars and potassium fertilization levels in both locations.

\begin{tabular}{|c|c|c|c|c|c|c|c|c|c|c|c|c|c|c|}
\hline cultivars & $\begin{array}{c}\mathrm{K} \\
\text { levels } \\
\left(\mathrm{kg} \cdot \mathrm{ha}^{-1}\right)\end{array}$ & $\begin{array}{l}\text { plant } \\
\text { height } \\
(\mathrm{cm})\end{array}$ & $\begin{array}{c}\text { stem } \\
\text { diameter } \\
(\mathrm{cm})\end{array}$ & $\begin{array}{c}\text { leaf area } \\
\left(\mathrm{cm}^{2} \cdot \text { plant }\right)\end{array}$ & $\begin{array}{c}\text { head } \\
\text { diameter } \\
(\mathrm{cm})\end{array}$ & $\begin{array}{c}\text { no. of } \\
\text { seeds } \\
\text { per head }\end{array}$ & $\begin{array}{c}1000 \\
\text { seed } \\
\text { weight }\end{array}$ & $\begin{array}{c}\text { hulls } \\
(\%)\end{array}$ & $\begin{array}{l}\text { fertility } \\
(\%)\end{array}$ & $\begin{array}{c}\text { yield } \\
\left(\text { ton.ha }^{-1}\right)\end{array}$ & $\begin{array}{l}\text { oil } \\
(\%)\end{array}$ & $\begin{array}{l}\text { oil yield } \\
\left(\text { ton.ha }^{-1}\right)\end{array}$ & $\begin{array}{l}\text { protein } \\
(\%)\end{array}$ & $\begin{array}{c}\text { protein } \\
\text { yield } \\
\left(\text { ton.ha }^{-1}\right)\end{array}$ \\
\hline \multicolumn{15}{|c|}{ AL-Rashidia location } \\
\hline \multirow{3}{*}{ Saturn } & 0 & $97.28 \mathrm{f}$ & $1.44 \mathrm{~g}$ & $2422.17 \mathrm{~h}$ & 18.59 & $986.05 d$ & $63.49 \mathrm{e}$ & 50.18 & 81.35 & 2.00 & $41.42 \mathrm{~cd}$ & $0.831 \mathrm{ef}$ & $13.31 \mathrm{~d}$ & $0.267 \mathrm{c}$ \\
\hline & 30 & $113.00 \mathrm{bc}$ & $2.24 \mathrm{~b}$ & $2895.29 d$ & 20.25 & $1128.96 \mathrm{~b}$ & $72.94 \mathrm{c}$ & 53.08 & 84.48 & 2.26 & $42.66 \mathrm{ab}$ & $0.964 \mathrm{c}$ & $13.46 \mathrm{~cd}$ & $0.303 \mathrm{~b}$ \\
\hline & 60 & $108.39 d$ & $1.96 \mathrm{~d}$ & $2523.71 \mathrm{e}$ & 19.57 & $1072.59 \mathrm{c}$ & $71.05 \mathrm{c}$ & 52.09 & 83.90 & 2.29 & $42.47 \mathrm{bc}$ & $0.974 \mathrm{c}$ & $13.93 \mathrm{~b}$ & $0.319 \mathrm{~b}$ \\
\hline \multirow{3}{*}{ Gordis } & 0 & $108.20 \mathrm{~d}$ & $1.76 \mathrm{f}$ & $2977.23 c$ & 20.62 & $1071.23 \mathrm{c}$ & $70.94 \mathrm{c}$ & 52.60 & 84.99 & 2.31 & $42.59 \mathrm{~b}$ & $0.984 \mathrm{c}$ & $13.29 \mathrm{~d}$ & $0.307 b$ \\
\hline & 30 & $120.38 \mathrm{a}$ & $2.44 a$ & $3295.66 a$ & 22.12 & $1251.94 a$ & $78.60 \mathrm{a}$ & 56.26 & 86.71 & 3.30 & $43.72 \mathrm{a}$ & $1.445 \mathrm{a}$ & $13.54 \mathrm{~cd}$ & $0.447 \mathrm{a}$ \\
\hline & 60 & $113.71 b$ & $2.14 \mathrm{c}$ & $3209.15 b$ & 21.03 & $1134.83 b$ & $75.39 \mathrm{~b}$ & 55.07 & 86.51 & 3.06 & $43.14 \mathrm{ab}$ & $1.320 \mathrm{~b}$ & $14.73 \mathrm{a}$ & $0.451 \mathrm{a}$ \\
\hline \multirow{3}{*}{ Majak } & 0 & $94.48 \mathrm{f}$ & $1.27 \mathrm{~h}$ & $2348.43 \mathrm{i}$ & 17.75 & $975.78 d$ & $62.38 \mathrm{e}$ & 49.18 & 80.20 & 1.89 & $40.84 d$ & $0.773 \mathrm{f}$ & $13.67 \mathrm{bc}$ & $0.258 \mathrm{c}$ \\
\hline & 30 & $110.55 \mathrm{~cd}$ & $2.16 \mathrm{c}$ & $2790.14 \mathrm{e}$ & 19.96 & $1117.25 b$ & $67.38 \mathrm{~d}$ & 51.63 & 83.54 & 2.22 & $42.32 b c$ & $0.941 \mathrm{~cd}$ & $13.96 b$ & $0.310 \mathrm{~b}$ \\
\hline & 60 & $105.21 \mathrm{e}$ & $1.85 \mathrm{e}$ & $2441.07 \mathrm{~g}$ & 18.57 & $998.05 \mathrm{~d}$ & $66.09 \mathrm{~d}$ & 50.16 & 82.66 & 2.12 & $41.45 \mathrm{~cd}$ & $0.880 \mathrm{de}$ & $14.79 \mathrm{a}$ & $0.314 b$ \\
\hline \multicolumn{15}{|c|}{ AL-Hamdanea location } \\
\hline \multirow{3}{*}{ Saturn } & 0 & 98.28 & 1.68 & 2521.17 & 18.60 & $1000.72 d$ & $65.56 \mathrm{e}$ & 51.44 & 81.82 & 2.04 & 40.42 & 0.825 & 13.38 & 0.272 \\
\hline & 30 & 115.67 & 2.64 & 2907.63 & 19.64 & $1107.29 c$ & $75.07 \mathrm{~b}$ & 52.73 & 84.06 & 2.34 & 41.42 & 0.970 & 13.89 & 0.325 \\
\hline & 60 & 110.06 & 2.08 & 2743.72 & 19.62 & $1084.25 c$ & $72.38 \mathrm{c}$ & 52.53 & 83.21 & 2.26 & 42.03 & 0.951 & 14.93 & 0.338 \\
\hline \multirow{3}{*}{ Gordis } & 0 & 108.87 & 2.13 & 3208.23 & 21.22 & $1083.23 c$ & $72.27 \mathrm{c}$ & 52.42 & 84.05 & 2.53 & 43.10 & 1.091 & 13.44 & 0.340 \\
\hline & 30 & 122.38 & 2.93 & 3379.66 & 22.35 & $1287.94 a$ & $78.13 \mathrm{a}$ & 54.57 & 86.47 & 3.06 & 44.07 & 1.348 & 13.70 & 0.419 \\
\hline & 60 & 116.37 & 2.62 & 3307.15 & 21.64 & $1171.83 \mathrm{~b}$ & $76.09 \mathrm{~b}$ & 53.29 & 85.94 & 2.88 & 43.72 & 1.263 & 15.21 & 0.439 \\
\hline \multirow{3}{*}{ Majak } & 0 & 95.48 & 1.57 & 2381.77 & 17.81 & $993.11 d$ & $63.38 \mathrm{f}$ & 50.27 & 80.64 & 1.82 & 40.48 & 0.741 & 13.99 & 0.253 \\
\hline & 30 & 113.55 & 2.41 & 2823.81 & 19.29 & $1097.92 \mathrm{c}$ & $67.93 \mathrm{~d}$ & 51.04 & 82.74 & 2.25 & 41.97 & 0.944 & 14.48 & 0.325 \\
\hline & 60 & 105.87 & 1.90 & 2583.07 & 18.67 & $1010.05 d$ & $66.67 \mathrm{de}$ & 50.67 & 81.87 & 1.99 & 41.24 & 0.823 & 15.42 & 0.307 \\
\hline
\end{tabular}

* The mean values within column followed by the different letter are significant at 0.01 and 0.05 probability levels, respectively. 
Mesopotamia J. of Agric. Vol. (42) No. (1) 2014
ISSN: 2224-9796 (Online)

ISSN: 1815-316 X (Print)

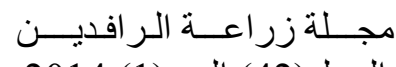

المجلد(42) العدد(1) 2014

Table (5): Analysis of variance F values for some growth characters, yield and yield components and quality in AL-Rashidia and AL-Hamdanea locations.

\begin{tabular}{|c|c|c|c|c|c|c|c|c|c|c|c|c|c|c|}
\hline \multirow[b]{2}{*}{ S.O.V } & \multirow[b]{2}{*}{ D.f } & \multicolumn{13}{|c|}{ M.S. for AL-Rashidia location } \\
\hline & & $\begin{array}{l}\text { plant } \\
\text { height } \\
(\mathrm{cm})\end{array}$ & $\begin{array}{c}\text { stem } \\
\text { diameter } \\
(\mathrm{cm})\end{array}$ & $\begin{array}{l}\text { leaf area } \\
\left(\mathrm{cm}^{2} \text {.plant }\right)\end{array}$ & $\begin{array}{l}\text { head } \\
\text { diameter } \\
(\mathrm{cm})\end{array}$ & $\begin{array}{c}\text { no. of } \\
\text { seeds } \\
\text { per head }\end{array}$ & $\begin{array}{l}\text { weight of } \\
\text { thousand } \\
\text { seed (g.) }\end{array}$ & $\begin{array}{r}\text { hulls } \\
(\%)\end{array}$ & $\begin{array}{c}\text { fertility } \\
(\%)\end{array}$ & $\begin{array}{c}\text { yield } \\
\left(\text { ton.ha }^{-1}\right)\end{array}$ & $\begin{array}{l}\text { oil } \\
(\%)\end{array}$ & $\begin{array}{l}\text { oil yield } \\
\text { (ton.ha }^{-1} \text { ) }\end{array}$ & $\begin{array}{l}\text { protein } \\
(\%)\end{array}$ & $\begin{array}{l}\text { protein } \\
\text { yield } \\
\left(\text { ton.ha }^{-1}\right)\end{array}$ \\
\hline Replications & 2 & 107.20 & 0.00271 & 16.25 & 0.5559 & 1516.037 & 1.463 & 2.2777 & 0.01444 & 0.1193 & 0.66333 & 0.019 & 0.6192 & 0.0028 \\
\hline $\mathrm{C}$ & 2 & $276.05^{* *}$ & $0.29015^{* *}$ & $1063322.67^{* *}$ & $14.8801^{* *}$ & $36176^{* *}$ & $214.2407^{* *}$ & $43.41721^{* *}$ & $37.028^{* * *}$ & $1.755337^{* *}$ & $5.9364^{* *}$ & $0.38785^{* *}$ & $0.736^{* *}$ & $0.03391^{* * *}$ \\
\hline $\mathrm{K}$ & 2 & $492.75^{\text {*** }}$ & $1.44973^{* *}$ & $392333.96^{* *}$ & $7.28973^{* *}$ & $55284.6^{* *}$ & $129.4141^{* *}$ & $20.55657^{* *}$ & $18.750^{* *}$ & $0.698781^{* *}$ & $3.7510^{* *}$ & $0.15954^{* *}$ & $2.814^{* *}$ & $0.01933^{* *}$ \\
\hline $\mathrm{C} \times \mathrm{K}$ & 4 & $7.7645^{*}$ & $0.01090^{* *}$ & $18941.49^{* *}$ & $0.1753^{\text {n.s. }}$ & $1414.8^{* *}$ & $5.0679037^{*}$ & $0.49550^{\text {n.s. }}$ & $0.605^{\text {n.s. }}$ & $0.13241^{\text {n.s. }}$ & $0.1103^{* *}$ & $0.02601^{* *}$ & $0.152^{* *}$ & $0.00293^{* *}$ \\
\hline Error & 16 & 2.67444 & 0.0010023 & 63.884 & 0.3105092 & 209.1620 & 1.3871704 & 1.1216167 & 0.583611 & 0.00988704 & 0.357500 & 0.0020915 & 0.03124 & 0.0001782 \\
\hline Total & 26 & & & & & & & & & & & & & \\
\hline S.O.V & D.f & \multicolumn{13}{|c|}{ M.S. for AL-Hamdanea location } \\
\hline Replications & 2 & 69.5559 & 0.5714925 & 79615.593 & 1.1945148 & 246.2593 & 6.9076704 & 4.01352593 & 20.06703 & 0.15007778 & 9.505170 & 0.0516340 & 0.67694 & 0.00192 \\
\hline $\mathrm{C}$ & 2 & $285.20^{* * *}$ & $0.86247^{* *}$ & $1258560.2^{* *}$ & $24.5269^{* * *}$ & $54436^{* *}$ & $203.3534^{* * *}$ & $17.33207^{* *}$ & $32.433^{* *}$ & $1.588344^{* * *}$ & $16.866^{* * *}$ & $0.399519^{* *}$ & $0.8745^{* *}$ & $0.02801^{* * *}$ \\
\hline $\mathrm{K}$ & 2 & $608.32^{\text {** }}$ & $1.69638^{* *}$ & $250136.5^{* *}$ & $3.40028^{* * *}$ & $43404^{* *}$ & $104.5393^{* *}$ & $4.447125^{* *}$ & $11.847^{* *}$ & $0.397511^{* * *}$ & $3.5077^{* *}$ & $0.093688^{* * *}$ & $6.0592^{* *}$ & $0.01487^{* *}$ \\
\hline $\mathrm{C} \times \mathrm{K}$ & 4 & $5.993^{\text {n.s. }}$ & $0.01432^{\text {n.s. }}$ & $15944.1^{\text {n.s. }}$ & $0.1458^{\text {n.s. }}$ & $3573.2^{* * *}$ & $5.3727148^{*}$ & $0.47580^{\text {n.s. }}$ & $0.093^{\text {n.s. }}$ & $0.01495^{\text {n.s. }}$ & $0.423^{\text {n.s. }}$ & $0.0039^{\text {n.s. }}$ & $0.071^{\text {n.s. }}$ & $0.00058^{\mathrm{n} . \mathrm{s}}$ \\
\hline Error & 16 & 4.17259 & 0.0184884 & 7249.093 & 0.3034398 & 545.6343 & 1.1626745 & 0.58128843 & 0.814612 & 0.02899861 & 0.616062 & 0.0052077 & 0.15615 & 0.0007076 \\
\hline Total & 26 & & & & & & & & & & & & & \\
\hline
\end{tabular}


Mesopotamia J. of Agric.

Vol. (42) No. (1) 2014
ISSN: 2224-9796 (Online)

ISSN: $1815-316 \mathrm{X}$ (Print)

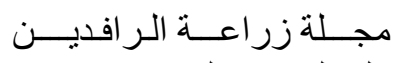

المجلد(42) العدد(1) 2014

تأثير مستويات التسميد البوتاسي في نمو وحاصل ونوعية أصناف من زهرة الثمس

(Helianthus annuus L.)

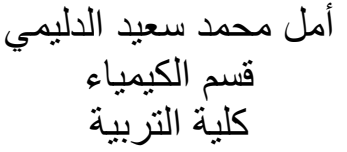

جامعة الموصل / العراق

\section{الخلاصة}

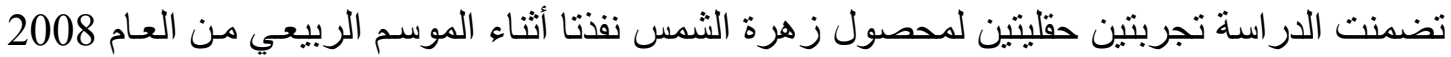

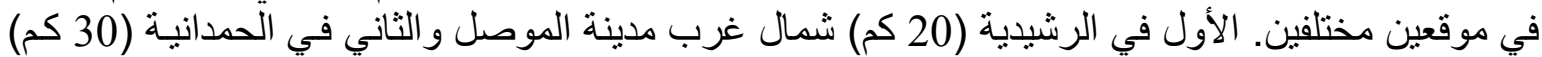

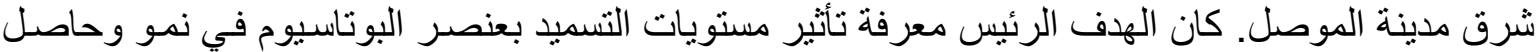

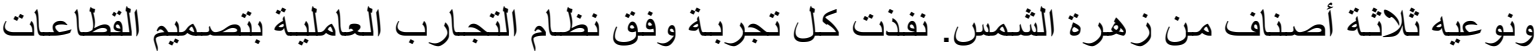

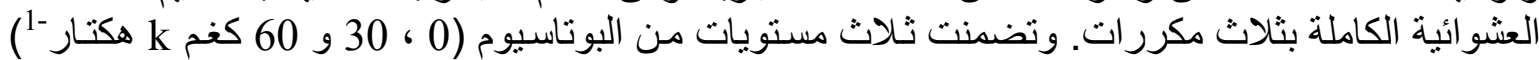

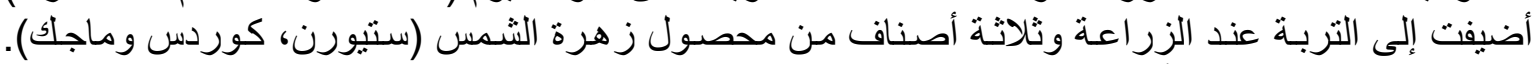
ويمكن تلخيص النتائج كالأتي:-

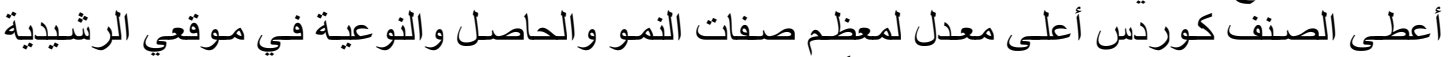

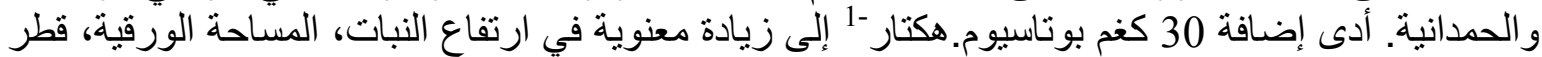

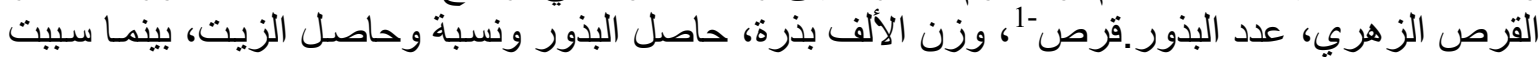

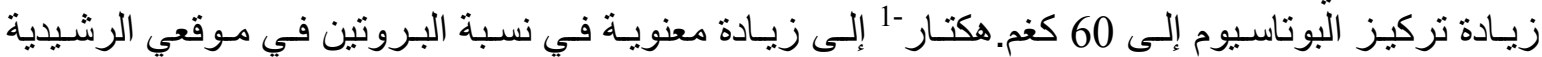

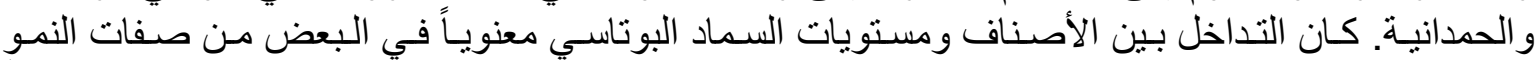

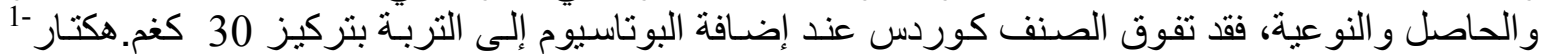

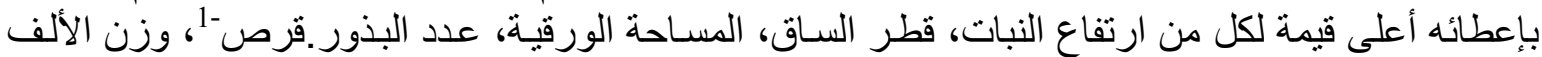

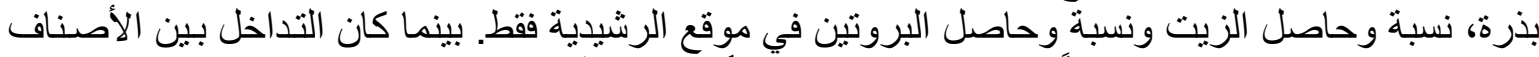

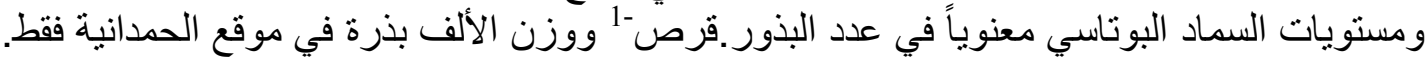

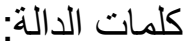

تاريخ نسلم البحث 17 / 4 / 2012 2012 وقبوله 15 / 10 /

\section{REFERENCES}

Abd EL-Samie, F.S.; M.E., EL-Bially and H., Mahfouz (1995). Influence of hand hoeing and plant spacing on productivity of Sunflower cultivars and accompanied weeds. Journal of Agriculture Science Mansoura University . 20 (6): $2673-2681$.

Agrawal, S.C.; M.S., Jolly and A.M., Sinha (1980). Foliar constituents of secondary food plants of tasar silk Antheraea mylitta. Indian Forester, 106 .12: 847 851.

Ahmad, R.; M., Saeed; T., Mahmood and A.F, Ehsanullah (2001). Yield potential and oil quality of two sunflower hybrids as affected by $\mathrm{K}$ application and season. International Journal of Agriculture Biology. 3(1): 51 - 53.

Annaduri, K.; P. Seshadri and S. Palaniappan (1994). Influence of potassium levels on yield and oil content Sunflower, soybean sequence. Potassium Resarch. 10,124-129.

Anonymous. (1980). Official Methods Of Analysis, Association Of Official Analytical Chemists, Washington, U.S.A.

Anonymous. (2001). Statistical Analysis Systems. SAS Institute Inc., Cary, NC, USA. 
Bergmann, W. (1965). Die Bedeutung Der Nahrstoffunters Unhungen Fur Die Bodenfruchtbarkeit. Sitzungsberichte Der DAL, Bd. XIV, H.9.

Black, C. A. (1965). Methods of Soil Analysis. Part 2. Chemical and Microbiological Properties. Amer. Soc. of Agronomy. Inc. Publisher Madison. USA.

Blamey, F. P. C.; D., Mould and J., Chapman (1979). Critical boron concentration in plant tissues of two sunflower cultivars. Agronomy Journal. 71 : $243-247$.

Brar, M. S. (2007). Evaluation Of The Effect of Potassium Application On The Yield and Quality Crop Under An Intensive Sunflower India. Res. Findings. E. ifcunsubsrcrib at ipipotash.org. No.12.

Carter, J. F. (1978). Sunflower Science and Technology. $2^{\text {nd }}$ ed. ASA, Mad. Wisconsin. USA: pp 505.

Chitdeshwari, T.; R. Shanmugasundram; S. Poongothai ; P. Savithri. (2002). Effect of teposyn micronutrient formulations on the yield and yield attributes of sunflower. Madras Journal of Agriculture. 89 ( 1-3) : 121-124.

Conley, S.P. and A.K., Barta (2003). Cultivar and Planting Date Effect Nusun Sunflower Yield and Oil Composition, Department of Agronomy, Univ. of Missouri, Columbia, Mo , 65211.U.S.A.

Duncan, B.O. (1955). Multiple range and multiple F test. Biometrics 11:1-42.

Govt, A. (2004). Effect of different levels of potassium on the growth yield and oil content of sunflower. Agronomy Journal. 66: 240-246.

Harmati, I. (1993). Effect of fertilizers on sunflower yields. Agrokemia-es-Talajtan, 42: 282-292.

Ibrahim, M.E.;E.A.EL-Absawy ;A.H .Selim and N.A. Gaafar (2003). Effect of nitrogen and phosphorus fertilization levels on growth, photosynthetic pigments yield and yield attributes of some sunflower cultivars (Helianthus annuus L.). Zagazig Journal Agriculture Research. 30 (4): 1223-1271.

Jackson, M. L. (1973). Soil Chemical Analysis. Prentice Hall of India Pvt., New Delhi.

Karim, N. and M. A. Hassan (2002). Effect of potassium and other fertilizing nutrients on the yield of sunflower. Journal of Agriculture. 32(3): 227-305.

Khan, M. A. (1999). Effect of potassium levels on the yield of sunflower (Helianthus annuus L.). Pakistan Journal of Biology Science. 2(2):402-403.

Lewis, D.C.; T.D. Potter and S.E. Weckert (1991). Effect of N,P and K fertilizers application on the seed yields of Sunflower grown on sandy soil and the prediction of N,P and K response by soil test Fertilizer.Research.28:185-190.

Mengel, K. and E.A., Kirkby (1982). Principles of Plant Nutrition. $3^{\text {rd }}$ Ed. Int. Institute Bern, Switzerland.

Mohamed, M. K.; K. E., EL-Habbak; G. M., Shams EL-Din and S. A., Shams (1992). Evaluation of some sunflower cultivars grown under three plant densities. Annals of Agriculture Science. Moshtohor. 30 (1): 1-10.

Mohammad, S. A.; M. Ashraf and N. A. Akram (2008). Effectiveness of potassium sulfate in mitigating salt induced adverse effect on different physic biochemical attributes in sunflower (Helianthus annuus L.). Pakistan Journal Ecology of Plant. 5:1-3. 
Nazakat, N.; G. Sarwar; M. Yousaf; T. Naseeb; A. Amir and M.J. Shah (2003). Yield and yield components of sunflower as affected by various potassium levels. Asian Journal of Plant Science. 2(7): 561: 562.

Osman, O. and B. H. Abolila (1984). Effect of levels of potassium on some agronomic characters and seed oil composition of sunflower. Festschrift For Acheron Planjenban 153:152-255.

Page, A.L.; R.H., Miller and D.R., Kenney (1982). Methods of Soil Analysis. Part (2) Agronomy no. 9 Madison. USA.

Pervaiz, A.; M. Ayub; M. Tanveer; Z. Amin; M.S. Sharar (1999). Effect of different sources and levels of potash on yield and oil content of spring sunflower. Journal of Biology Science. 2(3) 801-803.

Prunty, L.(1981). Sunflower cultivar performance as influenced by soil water and plant population. Agronomy Journal. 73: $257-260$.

Rathika, S.; C. Jayanth; S. Marimuthus and G. Vivek (2008). Nutrient recycling potential of IFS on yield attributes and yield of irrigated sunflower Madras Journal of Agriculture. 95 (1-6): 46-50.

Roga, A. D.; O., Osman and B. H. Abolila (1984). Effect of levels of nitrogen, phosphorus and potassium on some agronomic characters and seed oil composition of sunflower, Agronomy Journal. 241-245.

Salama, A.M. (1996). Response of three Sunflower cultivars to planting date and nitrogen fertilization. Journal of Agriculture Science. Mansoura Univ. 21 (5): $1657-1668$.

Sangoi, L. and N. D., Kruse (1993). Behavior of sunflower cultivars at different planting dates in the uplands, Pesquisa Agropecuria Brasileira. 28 (1): 81 91 .

Sarmah, P. C.; S. K., Katyal and A. S., Faroda (1994). Response of sunflower (Helianthus annuus L.) cultivars to fertility level and plant population. Agronomy Journal. 39 (1): 76 - 79.

Shinde, S. V.; K. T. Naphade; S. K. Kohale and G. R. Fulzele (1993). Effect of varying levels of potash on seed and oil yield of sunflower (Helianthus annuus L.). PKV Research Journal. 17:31-32.

Sirbu, M. and D. Ailincai (1992). Effect of long term Fertilizer application including NPK on the grain yields and quality of sunflower, Agronomy in Mold. 25:181-187.

Soleimanzadeh, H.; D. Habibi, M. R. Ardakani; F. Paknejad and F. Rejali (2010). Effect of potassium levels on antioxidant enzymes and malondialdehyde content under drought stress in sunflower (Helianthus annuus L.) American Journal of Biology Science. 5 (1): 56-61.

Steel, R. G. D. and J. H., Torrie (1980). Principles and Procedures Of Statistics. MC Grew Hill, New York.

Tandon, H. (1999). Methods of Analysis of Soil, Plants, Water and Fertilizers. Fertilizer Development and Consultation Organization, New Delhi, India, pp: 144.

Tisdale, S. L.; W.L., Nelson and J.D., Beaton (1985). Soil Fertility and Fertilizers. Macmillan. Pub. Co. New York. pp: 249-91. ISBN: 964-985. 